\title{
WSIS+10: the self-praising feast of multi- stakeholderism in internet governance
}

\author{
Francesca Musiani \\ MINES ParisTech, France, francesca.musiani@mines-paristech.fr
}

Published on 11 Apr 2013 | DOI: 10.14763/2013.2.121

\begin{abstract}
The World Summit on the Information Society (WSIS), two United Nations-sponsored conferences about information, communication and the establishment of a 21st century 'information society', took place in 2003 in Geneva and in 2005 in Tunis, setting the foundations for a 'multi-stakeholder' approach to global governance of information and communication technologies (ICTs). In February 2013, the Paris WSIS+10 review meeting has provided an occasion for scholars of internet governance actors to assess the present state of what was ten years ago - and still is - a set of experimental formats, procedures and processes for the governance of ICTs, seeking to reunite the private sector, governments and intergovernmental institutions and, civil society, under the auspices of 'multi-stakeholderism'. This article provides such an assessment and calls for a realistic and thorough assessment of multistakeholderism in ICT governance.
\end{abstract}

Keywords: Internet governance, WSIS+10, Internet Governance Forum (IGF), World Summit on the Information Society (WSIS), Knowledge society, Multi-stakeholderism

\section{Article information}

Received: 16 Mar 2013 Reviewed: 26 Mar 2013 Published: 11 Apr 2013

Licence: Creative Commons Attribution 3.0 Germany

Competing interests: The author has declared that no competing interests exist that have influenced

the text.

URL:

http://policyreview.info/articles/analysis/wsis10-self-praising-feast-multi-stakeholderism-internet-gov ernance

Citation: Musiani, F. (2013). WSIS+10: the self-praising feast of multi-stakeholderism in internet governance. Internet Policy Review, 2(2). https://doi.org/10.14763/2013.2.121

The World Summit on the Information Society (WSIS), two United Nations-sponsored conferences about information, communication and the establishment of a 21st century "information society", took place in 2003 in Geneva and in 2005 in Tunis. "We, the representatives of the peoples of the world, assembled in Geneva [...] declare our common desire and commitment to build a people-centred, inclusive and development-oriented Information Society [1]," began the Geneva Declaration of Principles, one of WSIS' founding documents, setting the foundations for a "multi-stakeholder" approach to global governance of information and communication technologies (ICTs). 
Ten years after the Geneva meeting, the first review meeting of the Summit, nicknamed WSIS +10, was held in February 2013 at the United Nations Educational, Scientific and Cultural Organization (UNESCO) headquarters in Paris, France. UNESCO Director General Irina Bokova inaugurated the meeting with the following words: "New technologies are opening tremendous possibilities for mutual understanding, for creating and sharing knowledge - everyone, everywhere, should have the skills and opportunities to participate in building this inclusive, knowledge society[2]." With the exception of the shift from "information society" to "knowledge society", a change we will come back to later in the article, not a lot appears to have changed content-wise in the ten years of existence of the WSIS process. Nonetheless, the WSIS+10 review meeting has provided an interesting occasion for scholars of internet governance arrangements like this author, who has started her career as a researcher investigating the WSIS process and its offspring, the Internet Governance Forum (IGF). It has been an occasion to assess, with more knowledge and experience at our disposal, the present state of what was ten years ago - and still is - a set of experimental formats, procedures and processes for the governance of ICTs, seeking to reunite the private sector, governments and inter-governmental institutions, and civil society, under the auspices of "multi-stakeholderism".

\section{WSIS, THE LANDMARK FOR MULTI-STAKEHOLDERISM IN INTERNET GOVERNANCE}

Arguably, the WSIS can be considered the first large-scale instance of the multi-stakeholder doctrine's application to the governance of ICTs. As defined by the Earth Summit Forum in 2002, multi-stakeholder processes "aim to bring together all major stakeholders [in a complex issue] in a new form of communication, decision-finding (and possibly decision-making) on a particular issue. They are also based on recognition of the importance of achieving equity and accountability [and] on democratic principles of transparency and participation, and aim to develop partnerships and strengthened networks between stakeholders [3]." The requirement that internet governance should be conducted according to multi-stakeholder principles was first stated at the WSIS summit, "arguably setting a new norm of customary international law [and marking] a departure from the earlier prevailing norm-expressed even by some governments (most notably the United States) - that internet governance was predominantly a private sector responsibility[4].”

WSIS's "summit" status (thus, not that of a permanent intergovernmental organisation), only enabled it to make recommendations crafted by consensus. However, because of the novelty of its approach and the vocabulary used to convey the urgency of addressing ICT issues in the global political arena, WSIS is widely regarded as having introduced, in the first half of the 200os, a shift in the understanding and the appropriations of ICT-related changes and the development of the internet. In terms of procedures, the entry into the discussions of organised civil society was noteworthy, and was considered by many as the first instance in which this relevant stakeholder for the future of ICTs had reclaimed its right to be heard (and even listened to!), alongside governments and private companies. In regard to internet governance, the most notable outcome of the WSIS process was the creation of the WGIG, the Working group on internet governance, and eventually, the Internet Governance Forum - both entities embodying the principle of multi-stakeholderism, albeit in different ways. 


\section{WGIG AND THE INTERNET GOVERNANCE FORUM}

The WGIG, a multi-stakeholder group itself, which had among its mandates the development of a "working definition of Internet governance[5]", further detailed the definition of multistakeholderism during its proceedings, identifying three main groups of actors and actions that they found to be particularly suited for policy development. Governments fit the "coordination and implementation" of public policy; the private sector's role expands beyond the "technical and economic fields" that the Geneva Declaration of Principles had talked about, to participate in the development of policy proposals. Finally, civil society's role is to engage in, and contribute to, "policy processes and policies that are more bottom-up, people-centred and inclusive[6]". In addition to producing the above-mentioned working definition of internet governance, which is still one of the most widely agreed upon and, which sets that "Internet governance is the development and application by governments, the private sector, and civil society, in their respective roles, of shared principles, norms, rules, decision making procedures and programmes, that shape the evolution and utilization of the Internet[7]", the WGIG further detailed that internet governance included, as well, important issues related to global politics, such as critical internet resources, security and safety of the global network, and issues related to its development and use. The implication that these critical issues, primarily technical but with important political implications, should fall under the multi-stakeholder approach, was not exempt from controversy - especially when, noting that "no global multi-stakeholder forum [existed] to address Internet-related public policy issues[8]," the WGIG report proposed the creation of a multi-stakeholder IGF linked to the United Nations. The establishment of the IGF, whose first meeting was held in Athens, Greece in 2006[9], can still be considered as one of the most prominent outcomes of the early WSIS processes. The Forum has since then met six other times, the last being Baku, Azerbaijan in 2012[10], and has seen its mandate renewed after the fifth meeting. The renewal of the mandate has been approved despite very tepid assessments by some governments, China first and foremost, of what the multi-stakeholder approach has been capable to achieve beyond its alluring label [11]. A detailed discussion of the controversial appraisals of the IGF would go beyond the scope of this article, but will be the subject of a future one.

\section{WSIS+10: THE MULTI-STAKEHOLDER FEAST OF NON- BINDING RECOMMENDATIONS}

Several UN instances left their stamp on the WSIS process - but coming from different standpoints and promoting different ideas. The organisation of the WSIS was assigned in 2003 and 2005 to the International Telecommunication Union (ITU), a UN agency of technical standardisation for the telecommunications sector, gathering states and private entities. In this context, the UNESCO - at the time a competing UN agency, more open to civil society participation and focused on "soft" themes of education, empowerment and communication rights - had maintained a low-profile, highlighting the limitations of the concept of "information society", widespread at the time, preferring to speak of "knowledge society".

Ten years later, for the recent WSIS+10 meeting in Paris, UNESCO's wish has been granted as, taking the lead in the organisation of WSIS's ten-year review meeting, the Organisation set the official theme of the gathering as "Towards Knowledge Societies for Peace and Sustainable Development", aimed at surpassing the emphasis placed on information itself, and going on to 
address aspects related to its structure, organisation and circulation. The final intended outcome of the meeting? A UNESCO statement, "Information and Knowledge for All an Expanded Vision and a Renewed Commitment", that would incorporate inputs from all parallel sessions, with the idea to inform and contribute to the WSIS review process. The major events in this process will be an evaluation in 2014, coordinated by the ITU, and the final review by the UN General Assembly, in 2015. The WSIS+10 participants' input to this process would take the form of "a non-binding recommendation grounded on a broad multistakeholder support[12]".

\section{HIGHS AND LOWS OF THE WSIS +10}

Proceedings opened on February 25, 2013, and in the UNESCO headquarters' hallways, conversations between a few academics that had witnessed with interest the beginnings of the WSIS/IGF process (and a few that, like this author, were born as researchers by witnessing them) revealed curiosity and expectation vis-à-vis both the content and the format of the meeting.

In particular at the end of the first, very formal day, the sensation of living a solemn moment could not prevent this author and her colleague[13] from feeling that they were simply been brought ten years back, when WSIS discourses were unveiling a somewhat naïve penchant for the digital as the vector of all utopias and hopes. The plenary sessions contributed to this impression, as well as the so-called "high-level debates", a misleading label actually indicating declarations by government officials, representatives of the private sector and organised civil society following one another's steps on the stage, with no time for questions and answers among them, or by the audience.

Columbia University professor Jeffrey Sachs' keynote introductory speech, about the necessity to bridge the inequalities of current ICT development, did little to mitigate this impression of déjà-vu, by repeatedly hammering the "digital revolution" label on the UNESCO Auditorium attendees. Even commentators more optimist about the overall relevance and usefulness of this gathering, like Humanity in Action Fellow Amy Hong - whose assessment is that WSIS+10 "drove home several central messages about the impact of information and communication technologies on our everyday lives and on our future prospects as a global society of interconnected citizens, [...and] helped explore is the progress the world has made in the last decade" - note that the meeting was "heavy on buzzwords such as 'the mobile revolution' and 'digital native”"[14].

Those delegates hoping for a more determined entrance into a renewed debate, where the diversity of the multi-stakeholder gathering could be fully leveraged, had some partial satisfaction during the next two days of the meeting, 26 and 27 February 2013, when dozens of parallel sessions took place to illustrate the hopes contained in ICTs, but also the challenges they bring about. Multilingualism, cultural and linguistic diversity, the promotion of freedom of expression, development of cyberscience, online privacy, digital security, ethical and societal current and emerging challenges of the information society: the parallel sessions explored in a more detailed and at times original way the issues and challenges, as well as the promises, of ICTs. Some of them, including one on "Contested Governance" organised by internet governance scholar Divina Frau-Meigs[15], and for which this author was a speaker, occasionally delved into a much-needed meta-reflection about the role of different stakeholders in global governance, and emphasised that one of the main goals for internet governance scholars and academics today should be to increase the awareness, by other stakeholders, that 
the definition of internet governance needs to be broadened beyond a handful of very codified and somewhat repetitious international gatherings, to take into account current core issues (transparency, openness, diversity, interoperability) and incorporate new central ones (infrastructure-based copyright enforcement, ownership, labour, content regulation, accountability)[16].

\section{MULTI-STAKEHOLDERISM OR “HAPPYTOWN”?}

"I did at least expect that there would be some attempt at a 'stocktaking' [...] What we are having instead is three days of 'happytalk' folks talking 'happy' about this that and the other[17]," community informatics scholar Michael Gurstein commented with sour irony at the end of the meeting. Even without going so far as defining WSIS +10 a Disneyland revival, or a HappyTown artificially preserved for the good of the "usual suspects"[18] who are materially able to visit Paris "on expense accounts"[19] - something that is, however, a serious barrier to in-person attendance to international gatherings for several stakeholders, one that should not be dismissed - the UNESCO-led meeting does not paint a very bright future for the multistakeholder format of engagement in global governance of the internet.

Opening up the dialogue to several, if not all[20], internet governance stakeholders, and codifying formats and procedures to do so, was in itself an important achievement of the WSIS/IGF process, and the answer to its shortcomings is certainly not to dispose of it entirely. Yet, the most important lesson we should take home from the Paris WSIS+10 meeting is that, ten years later, reaffirming the worthy existence of the arrangement is not enough.

As internet governance scholar Bill Drake has recently pointed out, "a substantial chunk of the actual decision-making that shapes the Internet and its use at both the national and global levels remains outside the ambit of the model of multistakeholderism [...] as such, that model is best conceived of as a critically important component of the distributed institutional architecture of Internet governance, rather than the embodiment of a 'paradigm shift'[21]". Hailed as such in the early days of the WSIS/IGF process, multi-stakeholderism in ICT governance is now in sore need of a realistic and thorough assessment, one that gets down to the "nitty gritty" details, dayto-day struggles, and material constraints of who participates, when, for what reasons, and how the practical results of this participation can be measured and leveraged for concrete next steps. This may entail, among other things, revisiting the "categories" of stakeholders outlined by WSIS, in favour of a more nuanced approach (what actors are regrouped under the label of civil society particularly comes to mind) that would acknowledge, in turn, the gap between "nominal and effective participation"[22] and devise creative tools to address it. Otherwise, as internet governance researcher Françoise Massit-Folléa and this author wrote a few years ago after having attended the fourth IGF in the fashionable Sharm-el-Sheikh, "the considerable weight of decisions taken elsewhere [is likely to] soon reduce this international forum" - as well as the broader processes shaping tomorrow's information society - "to a friendly conversation between true and false naives, under the disguise of enlightened debates[23]”. 


\section{REFERENCES}

- [1] http://www.itu.int/wsis/docs/geneva/official/dop.html

- [2] http://unesdoc.unesco.org/images/o021/o02197/219754M.pdf

- [3] http://www.earthsummit2002.org/msp/index.html

- [4] Malcolm, Jeremy (2008). Multi-Stakeholder Governance and the Internet Governance Forum. Wembley, WA: Terminus Press. (p. 322).

- [5] Geneva Plan of Action.http://www.itu.int/wsis/documents/doc_multi.asp?lang=en\&id=116o 0

- [6] WGIG (2005). Report of the Working Group on Internet Governance, p. 18.

- [7] WGIG (2005). Report of the Working Group on Internet Governance, p. 18.

- [8] WGIG (2005). Report of the Working Group on Internet Governance, p. 18.

- [9] http://www.intgovforum.org/cms/athensmeeting

- [10] http://www.intgovforum.org/cms/2012-igfbaku

- [11] http://rconversation.blogs.com/rconversation/2009/11/china-isnt-happy-with-the-igf.html

- [12] http://www.ifla.org/news/closing-of-the-wsis10-review-meeting

- [13] Schafer, Valérie (2013). Première réunion d'examen du SMSI+10. Institut des Sciences de la Communication du CNRS. http://www.iscc.cnrs.fr/spip.php?article1751

- [14] Hong, Amy (2013). WSIS+10: The Global Information Boom Leaves Billions Behind. MediaShift,

http://www.pbs.org/mediashift/2013/o3/wsis10-the-global-information-boom-leaves-billion s-behindo66.html

- [15] "Contested Governance: Exploring the Evolving Policy $\square$ making Environment and Considering Collaborative Solutions from the Netroots", WSIS+10 session organised by Divina Frau-Meigs, February 27th, 2013.

- [16] Author's notes from the session, February 27th, 2013.

- [17] Gurstein, Michael (2013). Making HappyTalk in Paris; Disneyland and the WSIS+10 Review. http://gurstein.wordpress.com/2013/o2/26/making-happytalk-in-parisdisneyland-and-the-wsis-10-review/

- [18] Drake, William (2011). Multistakeholderism: External Limitations and Internal Limits. MIND: Multistakeholder Internet Dialog, Co:llaboratory Discussion Paper Series No. 2, Internet Policymaking, 68-72, Berlin: Co:llaboratory.

- [19] Gurstein, Michael (2013). Making HappyTalk in Paris; Disneyland and the WSIS+10 Review. http://gurstein.wordpress.com/2013/o2/26/making-happytalk-in-parisdisneyland-and-the-wsis-10-review/

- [20] Hintz, Arne and Stefania Milan (2009). “At the Margins of Internet Governance: Grassroots Tech Groups and Communication Policy”, International Journal of Media and Culture Policy, 5 (1-2): 23-38.

- [21] Drake, William (2011). Multistakeholderism: External Limitations and Internal Limits. MIND: Multistakeholder Internet Dialog, Co:llaboratory Discussion Paper Series No. 2, Internet Policymaking, 68-72, Berlin: Co:llaboratory.

- [22] Drake, William (2011). Multistakeholderism: External Limitations and Internal Limits. MIND: Multistakeholder Internet Dialog, Co:llaboratory Discussion Paper Series No. 2, Internet Policymaking, 68-72, Berlin: Co:llaboratory.

- [23] Massit-Folléa, Françoise and Francesca Musiani (2009). Recollections of Egypt. Comments on the Fourth Annual Meeting of the Internet Governance Forum, Vox Internet, http://www.csi.ensmp.fr/voxinternet/www.voxinternet.org/spipc8dd.html?article340 